\title{
Implementasi Program Tahfidzul Al-Qur'an Jilid 5 Bagi Peserta Didik Di Madrasah Ibtidaiyah Muhammadiyah 02 Ambulu Jember
}

\author{
Khusnul Khovia \\ UIN Kiai Haji Achmad Siddiq Jember \\ khoviakhusnul@gmail.com \\ DOI:10.35719/educare.v2i2.60
}

\begin{abstract}
The purpose of this study is to describe the planning, implementation and evaluation of the tahfidzul Al-Qur'an program for students volume 5 at MI Muhammadiyah 02 Pontang Ambulu Jember. This study uses a qualitative approach and the technique of determining data sources using purposive sampling. Collecting data through observation, interviews and documentaries. Data analysis, descriptive qualitative with data reduction steps, data presentation, conclusion drawing/verification. To check the validity of the data using triangulation of sources and techniques. The results of the research show: (1) Planning the tahfidzul Al-Qur'an program for students volume 5 at MI Muhammadiyah 02 Pontang Ambulu Jember, namely: determining the goal of memorizing 2 letters Al-Insyiqaq and Al-Muthoffifin, instilling a love of the Qur'an since early, Content of material, determine method, Determination of media, Determination of evaluation. (2) The implementation of the tahfidzul Al-Qur'an program for students volume 5 at MI Muhammadiyah 02 Pontang Ambulu Jember, namely: students memorizing letters Al-Insyiqaq and Al-Muthoffifin, reading letters according to makhraj and tajwid, Submission of material by teachers, using tilawati method by listening, imitating, reading together and repeatedly, using Juz 'Amma, Al-Qur'an and murottal media. (3) Evaluation of the tahfidzul Al-Qur'an program for students volume 5 at MI Muhammadiyah 02 Pontang Ambulu Jember, namely: evaluation of objectives, evaluation of material based on the target of memorizing letters Al-Insyiqaq and Al-Muthoffifin and not experiencing difficulties, evaluation of methods, formative evaluation at the end of each lesson and letter increase.
\end{abstract}

Keywords: Tahfidzul Al-Qur'an; Student; Madrasah Ibtidaiyah 


\begin{abstract}
Abstrak
Tujuan penelitian ini mendeskripsikan perencanaan, pelaksanaan dan evaluasi program tahfidzul Al-Qur'an peserta didik jilid 5 di MI Muhammadiyah 02 Pontang Ambulu Jember. Penelitian ini menggunakan pendekatan kualitatif dan tehnik penentuan sumber data menggunakan purposive sampling. Pengumpulan data melalui observasi, wawancara dan dokumenter. Analisis data, kualitatif deskriptif dengan langkah reduksi data, penyajian data, penarikan kesimpulan/verifikasi. Untuk mengecek keabsahan data menggunakan triangulasi sumber dan tehnik. Hasil penelitiannya menunjukkan: (1) Perencanaan program tahfidzul Al-Qur'an untuk peserta didik jilid 5 di MI Muhammadiyah 02 Pontang Ambulu Jember yaitu: penentuan tujuan hafalan 2 surat Al-Insyiqaq dan Al-Muthoffifin, menanamkan cinta Al-Qur'an sejak dini, Isi materi, menentukan metode, Penentuan media, Penentuan evaluasi. (2) Pelaksanaan program tahfidzul Al-Qur'an untuk peserta didik jilid 5 di MI Muhammadiyah 02 Pontang Ambulu Jember yaitu: peserta didik menghafal surat Al-Insyiqaq dan Al-Muthoffifin, membaca surat sesuai makhraj dan tajwid, Penyampaian materi oleh guru, menggunakan metode tilawati dengan mendengarkan, menirukan, membaca bersama-sama dan berulang-ulang, Penggunaan media Juz 'Amma, Al-Qur'an dan murottal. (3) Evaluasi program tahfidzul Al-Qur'an untuk peserta didik jilid 5 di MI Muhammadiyah 02 Pontang Ambulu Jember yaitu: evaluasi tujuan, evaluasi materi berdasarkan target menghafal surat Al-Insyiqaq dan Al-Muthoffifin dan tidak mengalami kesulitan, evaluasi metode, evaluasi formatif setiap akhir pembelajaran dan kenaikan surat.
\end{abstract}

\title{
Kata Kunci: Tahfidzul Al-Qur'an; Peserta Didik; Madrasah Ibtidaiyah
}

\section{PENDAHULUAN}

Pendidikan memegang peranan penting dalam mencerdaskan kehidupan bangsa. Melalui pendidikan inilah suatu bangsa dapat menjadi bangsa yang tangguh, mandiri, berkarakter dan berdaya saing. Selain itu, pendidikan juga dipandang sebagai salah satu aspek yang memiliki peranan pokok dalam mempersiapkan sekaligus membentuk generasi muda di masa yang akan datang. Keberhasilan pembangunan suatu bangsa ditentukan oleh kualitas pendidikan warga bangsa tersebut. Karena dengan pendidikan yang baik manusia dapat mencapai kesejateraan hidup, mengembangkan potensi dirinya, mewujudkan kehidupan lebih baik dan berpatisipasi secara lebih 
aktif dalam pembangunan. Hal itu disebutkan dalam Undang-Undang No. 20 Tahun 2003 tentang Sisdiknas pasal 3 secara tegas dinyatakan bahwa:

Pendidikan nasional berfungsi mengembangkan kemampuan dan membentuk watak serta peradaban bangsa yang bermartabat dalam rangka mencerdaskan kehidupan bangsa, bertujuan untuk berkembangnya potensi peserta didik agar menjadi manusia beriman dan bertaqwa kepada Tuhan Yang Maha Esa, berakhlak mulia, sehat, berilmu cakap, kreatif, mandiri dan menjadi warga negara yang demokratis serta bertanggung jawab ${ }^{1}$.

Pendidikan sebagai kebutuhan pokok manusia tentu mengalami perkembangan, baik dari segi sistem, penjabaran teknisnya, termasuk teknologinya. Pendidikan diuraikan beberapa ahli seperti Ki Hajar Dewantara mengartikan pendidikan adalah segala daya upaya untuk memajukan budi pekerti, pikiran serta jasmani anak, agar dapat memajukan kesempurnaan hidup yaitu hidup dan menghidupkan anak yang selaras dengan alam dan masyarakatnya.

Demikian pentingnya pendidikan, sebagaimana ayat yang pertama turun kepada Nabi Muhammad SAW adalah perintah membaca. Sebagaimana firman Allah SWT dalam surah Al-Alaq ayat 1-5.

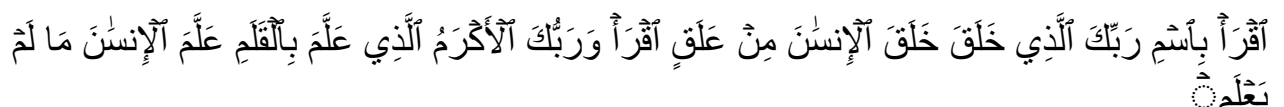

Artinya: "bacalah dengan (menyebut) nama tuhanmu yang menciptakan, dia telah menciptakan manusia dari segumpal darah. bacalah, dan tuhanmulah yang maha pemurah, yang mengajar (manusia) dengan perantaran kalam, dia mengajar kepada manusia apa yang tidak diketahuinya". ${ }^{2}$

Berdasarkan ayat tersebut diatas menegaskan bahwa membaca merupakan perintah yang pertama kali turun sebelum perintah-perintah lain, yang berarti bahwa pendidikan merupakan pilar utama dan mendasar untuk memahami dan mendalami, serta mengamalkan perintah-perintah yang lain. Jadi ayat tersebut berimplikasi terhadap urgennya pendidikan pada manusia.

\footnotetext{
${ }^{1}$ Undang-Undang No. 20 Tahun 2003 Sisdiknas pasal 3

${ }^{2}$ Departemen Agama RI, Aisyah Al-Qur'an dan TerjemahanUntuk Wanita (Bandung: Jabal, 2010), 597.
} 
Al-Qur'an menjadi pegangan hidup bagi manusia, baik yang menyangkut urusan dunia ataupun akhirat. Dalam Al-Qur'an ada banyak ayat yang menjelaskan bagaimana hidup bermasyarakat, bagaimana berhubungan dengan komunitas masyarakat, dan toleransi agama. Tidak hanyak itu Al-Qur'an juga mengajarkan agar kehidupan di dunia ini menjadi washillah atau jalan menuju kehidupan yang lebih abadi, yakni kehidupan akhirat. Dengan kata lain, harus ada keseimbangan antara kehidupan dunia dan akhirat. $^{3}$

Membaca Al-Qur'an merupakan suatu amalan yang berguna pada diri seorang mus-lim, karena dengan membaca Al-Qur'an seseorang dapat memahami,menghayati serta mengamalkan isi kandungan yang terdapat di dalamnya sehingga dengan demikian pem-belajaran Al-Qur'an sudah menjadi tuntutan yang harus dipenuhi oleh setiap individu seorang muslim. ${ }^{4}$

Menghafal Al-Quran merupakan suatu keutamaan yang besar dan posisi itu selalu didambakan oleh semua orang yang besar dan orang yang bercita-cita tulus, serta berharap pada kenikmatan duniawi yang ukhrawi agar manusia nanti menjadi hamba Allah dan dihormati dengan penghormatan yang sempurna. Tidaklah seseorang dapat meraih tuntunan dan keutamaan tersebut, yang menjadikannya masuk ke dalam deretan malaikat baik kemuliaan maupun derajatnya, kecuali dengan cara mempelajari dan mengamalkannya. ${ }^{5}$

Mengenai hal ini Rasuluallah SAW bersabda:

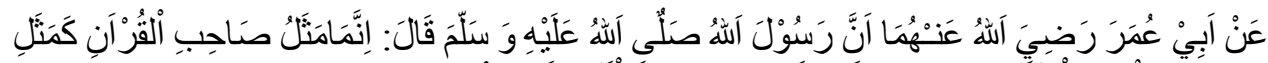

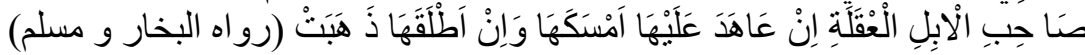

${ }^{3}$ Rofiul, Wahyudi dkk, Metode Cepat Hafal Al-Qur'an. (Yogyakarta: Semesta Hikmah, 2017), 10.

${ }^{4}$ Intan Alivia Permadani and Abdul Karim. "Penerapan Metode Dirosati Dalam Mengembangkan Kemampuan Baca Sejak Dini Di TPQ Nurul Falah Bringin Lawang Jenggawah". NGARSA: Journal of Dedication Based on Local Wisdom 1, no. 1 (February 24, 2021): 23.

${ }^{5}$ Sa'dulloh, 9 Cara Praktis Menghafal Al-Qu'ran, (Jakarta: Gema Insani, 2008), 23. 
seperti pemilik unta yang diikat .Jika ia menjaganya berarti ia telah mengikatinya ,namun jika ia melepaskan ikatan itu niscaya unta akan pergi.’(HR .Bukhori dan Muslim).

Hadist tersebut menjelaskan bahwa seseorang menghafal Al-Qur'an diharapkan selalu mendekatkan diri kepada Allah SWT, dengan banyak membaca dan menghafalnya, apabila ia mencintai Al-Qur'an sudah tentu ia akan berusaha memperbaiki hafalannya, sebab orang yang akan diangkat derajatnya oleh Allah SWT pasti akan mendapatkan ujian.

Salah satu komponen dalam sistem pendidikan adalah adanya peserta didik merupakan komponen yang sangat penting dalam sistem pendidikan, sebab seseorang tidak bisa dikatakan sebagai pendidik apabila tidak ada yang didiknya. Abu Ahmadi juga menuliskan tentang pengertian peserta didik, peserta didik adalah anak yang belum dewasa, yang memerlukan usaha, bantuan, bimbingan orang lain untuk menjadi dewasa, guna dapat melaksanakan tugasnya sebagai makhluk Tuhan, sebagai umat manusia, sebagai warga negara, sebagai anggota masyarakat dan sebaga suatu pribadi atau individu. ${ }^{6}$

Efektifitas dalam belajar al-Qur'an sangat diperlukan, terlebih jika menginginkan untuk dapat menghafalkannya. Sebuah wadah dalam pembelajaran atau semacam progam mengaji juga menjadi faktor pendukung keberhasilan seorang untuk dapat membaca dan menghafalkan al-Qur'an. Seringkali upaya untuk menghafal Al-Qur'an berhadapan dengan beberapa kendala. Mulai dari waktu yang tersedia kemampuan menghafal, hingga hilangnya hafalan yang sebelumnya telah diperoleh. Hal tersebut akan membuat beberapa peserta didik kurang bersemangat dalam menghafal Al-Qur'an.

Seperti yang dikemukakan oleh Ahmad Salim Badwilan yang dikutip oleh Ahmad Rosidi menghafal Al-Qur'an bukanlah tugas yang mudah, sederhana, serta bila dilakukan oleh kebanyakan orang tanpa meluangkan

\footnotetext{
${ }^{6}$ Abu Ahmadi, Ilmu Pendidikan, (Jakarta: Rineka Cipta, 2001), 251.
} 
waktu yang khusus, kesungguhan mengerahkan kemampuan dan keseriusan dalam menyelesaikannya. Dorongan dan hambatan selalu berjalan seiring dalam proses menghafal Al-Qur'an dan salah satunya hambatannya sebagai berikut: 1) Banyak dosa dan maksiat. 2) Tidak senantiasa mengikuti, mengulang-ulang, dan memperdengarkan hafalan Al-Qur'an. 3) Perhatian yang lebih pada urusan-urusan dunia menjadikan hati terkait dengannya, sehingga tidak bisa menghafal dengan mudah. 4) Menghafal banyak ayat pada waktu yang singkat dan pindah kelainnya sebelum menguasai dengan baik. 5) Semangat yang tinggi untuk menghafal di permulaan membuatnya menghafal banyak ayat tanpa menguasainya dengan baik. ${ }^{7}$

Disamping itu kendala yang dihadapi sangat beragam sesuai dengan problem yang mereka temui, kuat lemahnya semangat tergantung pada motivasi yang berhasil mereka tanamkan pada diri mereka dihadapkan pada kulminasi yang sulit. Motivasi yang kuat, baik dari dalam dari (intrinsik) maupun dari luar (ekstrinsik) akan memberikan kekuatan pada semangat peserta didik untuk konsentrasi untuk menghafal. ${ }^{8}$

Berdasarkan wawancara dengan Kepala Madrasah realita dilapangan menunjukkan bahwa peserta didik tidak memiliki kemauan belajar yang tinggi. Hal ini menunjukkan bahwa sebagian peserta didik tidak mempunyai motivasi yang kuat untuk belajar. Peserta didik masih menganggap kegiatan belajar tidak menyenangkan dan memilih kegiatan lain diluar kontek belajar seperti bergaul dengan teman sebaya. Dalam belajar setiap orang pasti mengalami hambatan-hambatan atau kesulitan-kesulitan yang timbul pada diri peserta didik atau lingkungan peserta didik . Sebab tidak dapat disangkal bahwa belajar, seseorang dipengaruhi oleh berbagai faktor. Faktor-faktor yang mempengaruhi banyak jenisnya, tetapi, dapat digolongkan menjadi dua secara umum yaitu: faktor intern dan faktor ekstren.

\footnotetext{
${ }^{7}$ Ahmad Rosidi, Strategi Pondok Tahfidz Al-Qur'an Dalam Meningkatkan Motivasi Menghafal Al-Qur'an. (Malang: UIN Maulana Malik Ibrahim, 2015), 4-5. 56.

${ }^{8}$ Slameto, Belajar dan Faktor-Faktor Yang Mempengaruhi. (Jakarta: Bima Aksara 1988),
} 
Faktor-faktor tersebut perlu diketahui tidak hanya oleh peserta didik , tetapi juga guru sebagai tenaga pendidik. Dengan demikian juga mengetahui bentuk motivasi yang bagaimana harus digunakan untuk meningkatkan gairah belajar peserta didik. Peranan guru dalam menumbuhkan motivasi ekstrinsik menjadi sangat banyak. Membangkitkan motivasi ekstrinsik menjadi kewajiban guru diharapkan lambat laun akan timbul kesadaran sendiri pada anak untuk belajar. Jadi pada dasarnya sasaran guru adalah meningkatkan motivasi peserta didik.

Dalam kegiatan belajar mengajar harus ada yang dilakukan oleh guru untuk meningkatkan motivasi dalam belajarnya. Hal ini bertujuan untuk memotivasi peserta didik agar mereka memiliki semangat dalam belajar dan dapat mencapai prestasi yang optimal. Oleh karena itu, guru harus mempunyai semangat untuk meningkatkan motivasi belajar peserta didik. Motivasi pembelajaran penting dilakukan dengan tujuan agar peserta didik tidak merasa bosan dan senang dalam menjalaninya. Guru bisa memotivasi peserta didik dengan pemberian angka, memberikan pujian, memberikan beapeserta didik, memberi ulangan, adanya kompetisi, dan bisa berupa pemberian hukuman. ${ }^{9}$

Dalam proses belajar mengajar, jauh lebih urgen dari materi, sebuah proses belajar mengajar bisa dikatakan tidak berhasil, apabila materi dalam proses pembelajaran tidak didukung oleh yang bagus/baik. Meliputi beberapa bagian-bagian pembelajaran yaitu: tujuan, metode, materi, media dan evaluasi. Dikatakan berhasil apabila tujuan dan akhir dari pembelajaran itu tercapai seperti juga dalam menghafal Al-Qur'an yang baik akan berpengaruh pada kualitas hafalan yang baik pula dan proses belajar mengajar berjalan secara efektif dan efisien. ${ }^{10}$

Alasan peneliti memilih di MI Muhammadiyah 02 berdasarkan

\footnotetext{
${ }^{9}$ Sadirman A. M, Interaksi \& Motivasi Belajar Mengajar. (Jakarta:PT. Raja Grafindo Persada, 2012), 92.

${ }^{10}$ Ahmad Rosidi, Strategi Pondok Tahfidz Al-Qur'an, 8.
} 
observasi awal adalah lembaga yang melaksanakan program full day school dimulai dari pagi sampai sore dan di sekolah peserta didik yang ada di naungan MI Muhammadiyah 02 belajar sambil bermain dan itu membuat peserta didik tidak bosan ketika ada di sekolah. MI Muhammadiyah 02 juga menanamkan hafalan Al-Qur'an untuk peserta didik dimana fase anak untuk bermain dan lembaga memberikan target untuk menghafal Juz 'Amma dan program tahfidzul Al-Qur'an tersebut merupakan kewajiban kepada peserta didik yang ada di naungan lembaga MI Muhammadiyah 02. Program tahfidzul Al-Qur'an yang merupakan kegiatan ekstrakurikuler. Alasannya memilh jilid 5 karena di dalamnya ada beberapa surat untuk menghafal Juz 'Amma dan ketika dia naik jilid 6 dia harus menyiapkan mental untuk setoran hafalan dimulai dari jilid 1-6 ditambah hafalan dari jilid 6 itu sendiri.

Hafalan Juz 'Amma yang ada dilembaga MI Muhammadiyah 02 Pontang untuk memberantaskan buta huruf, secara tidak langsung mengenalkan kepada peserta didik akan pentingnya menghafal Al-Qu'ran sebagai pedoman hidup bagi manusia agar tidak tersesat ke jalan yang tidak diridhoi Allah. Berdasarkan latar belakang tersebut, peneliti tertarik untuk meneliti tentang "Impelementasi Program Tahfidzul Al-Qur'an Untuk Peserta didik Jilid 5 di MI Muhammadiyah 02 Pontang Ambulu Kabupaten Jember".

\section{METODE PENELITIAN}

Penelitian ini menggunakan pendekatan kualitatif, dalam menentukan sumber data menggunakan purposive sampling. Untuk mengumpulkan data digunakan metode sebagai berikut: a) Observasi, b) Wawancara dan c) Dokumenter. Analisis data menggunakan analisis data kualitatif deskriptif dengan langkah-langkah: reduksi data, penyajian data, penarikan kesimpulan/verifikasi. Untuk keabsahan data peneliti menggunakan triangulasi sumber dan tehnik.

\section{HASIL DAN PEMBAHASAN TEMUAN}




\section{Perencanaan Program Tahfidzul Al-Qur'an untuk Peserta Didik Jilid 5 di MI Muhammadiyah 02 Pontang Ambulu Jember}

Perencanaan adalah hubungan antara apa yang ada sekarang dengan bagaimana seharusnya yang berkaitan dengan kebutuhan, penentuan tujuan, prioritas, program dan alokasi sumber. ${ }^{11}$ Perencanaan implementasi program tahfidzul Al-Qur'an untuk peserta didik jilid 5 di MI Muhammadiyah 02 Pontang Ambulu Kabupaten Jember dalam perencanaan tujuan yaitu mempermudah peserta didik menghafal surat Al-Insyiqaq dan Al-Muthoffifin, menambah hafalan surat Al-Insyiqaq dan Al-Muthoffifin, menanamkan cinta Al-Qur'an sejak dini dan membaca surat Al-Insyiqaq dan Al-Muthoffifin sesuai makhraj dan tajwid.

Pada hakikatnya bila suatu kegiatan direncanakan lebih dahulu, maka tujuan dari kegiatan tersebut akan lebih terarah dan lebih dalam merencanakan pengajaran. Tujuan adalah komponen yang utama dalam proses pembelajaran. Apapun yang direncanakan termasuk pengemasan materi pelajaran diarahkan untuk mencapai tujuan pembelajaran secara optimal. Sebelum dilakukan pengemasan materi pelajaran sebaiknya ditentukan terlebih dahulu tujuan yang harus dicapai baik tujuan dalam bentuk perubahan perilaku yang bersifat umum, maupun perilaku terukur dalam bentuk hasil belajar. ${ }^{12}$

Berdasarkan dari materi yang diberikan oleh Ustadz Muhtar Winarso yaitu surat Al-Insyiqaq dan Al-Muthoffifin. Ada beberapa hal yang perlu diperhatikan dalam menetapkan materi pelajaran, antara lain: 1) Materi pelajaran hendaknya sesuai dengan tercapainya tujuan instruksional. 2) Materi pelajaran hendaknya sesuai dengan tingkat pendidikan/perkembangan peserta didik pada umumnya. 3) Materi pelajaran hendaknya terorganisasi

\footnotetext{
${ }^{11}$ Hamzah B. Uno, Perencanaan Pembelajaran, (Jakarta: Bumi Aksara, 2016), 1.

${ }^{12}$ Wina Sanjaya, Perencanaan Dan Desain Sistem Pembelajaran, (Jakarta: Prenadamedia Group, 2008), 151.
} 
secara sistematik dan berkesinambungan. ${ }^{13}$

Materi atau isi pelajaran berkenaan dengan bahan pelajaran yang harus dikuasai peserta didik sesuai dengan tujuan pelajaran. Teori tersebut sesuai dengan perencanaan materi yang telah direncanakan oleh ustadz di MI Muhammadiyah 02 Pontang Ambulu Kabupaten Jember.

Perencanaan program tahfidzul Al-Qur'an dalam menentukan metode yaitu: metode tilawati tetapi metode ini tidak seperti strategi pada metode tilawati yang digunakan hanya tehnik klasikal yaitu Ustadz memberikan contoh terlebih dahulu (mendengarkan), menirukan bacaan kemudian peserta didik membaca bersama-sama. Metode mengajar merupakan salah satu cara yang dipergunakan guru dalam mengadakan hubungan dengan peserta didik pada saat berlangsungnya pengajaran. Sedangkan metode pembelajaran ialah jalan atau cara-cara yang digunakan guru dan murid dalam proses pembelajaran. ${ }^{14}$

Perencanaan program tahfidzul Al-Qur'an dalam menentukan media yaitu: Juz 'Amma, Al-Qur'an pojok dan murottal. Supaya penggunaan media dapat berjalan dengan baik, perlu membuat persiapan yang baik pula. Media pembelajaran harus meningkatkan motivasi peserta didik. Selain itu, merangsang peserta didik mengingat apa yang sudah dipelajari, selain memberikan rangsangan belajar baru. Media yang baik akan mengaktifkan peserta didik dalam memberikan tanggapan, umpan balik, dan mendorong peserta didik untuk melakukan praktik-praktik yang benar. ${ }^{15}$

Berdasarkan teori Azhar Arsyad kriteria yang perlu diperhatikan dalam memilih media yaitu sesuai dengan tujuan yang ingin dicapai, tepat untuk mendukung isi pelajaran, praktis, luwes dan bertahan, guru terampil dalam menggunakannya, pengelompokan sasaran. ${ }^{16}$ Penggunaan media di MI Muhammadiyah Pontang Ambulu Jember telah sesuai dengan teori yang

\footnotetext{
${ }^{13}$ Suryosubroto, Proses Belajar Mengajar di Sekolah, (Jakarta: Rineka Cipta, 2002), 42.

${ }^{14}$ Ihsan El Khuluqo, Belajar dan Pembelajaran, (Yogyakarta: Pustaka Pelajar, 2017),130.

${ }^{15}$ Hamdani, Strategi Belajar Mengajar (Bandung: CV Pustaka Setia, 2011), 72-73.

${ }^{16}$ Azhar Arsyad, Media Pembelajaran (Jakarta: Rajawali Pers, 2014), 74-76.
} 
dikemukakan oleh Azhar Arsyad. Penggunaan media cetak seperti Juz 'Amma dan Al-Qur'an pojok yang menjadi pegangan khusus baik untuk Ustadz/Ustadzah maupun peserta didik telah menyesuaikan dengan tujuan yang ingin di capai baik oleh pendidik maupun peserta didik, tepat untuk mendukung dalam pembelajaran menghafal surat Al-Insyiqaq dan Al-Muthoffifin melalui metode tilawati. Media dalam metode tilawati ditunjang dengan alat bantu pembelajaran, seperti buku panduan program tahfidzul Al-Qur'an MI Muhammadiyah 02. ${ }^{17}$ Peralatan multimedia yang digunakan seperti murottal. Oleh karena itu media merupakan alat untuk memudahkan interaksi antara pendidik dan peserta didik dalam pembelajaran. ${ }^{18}$

Perencanaan program tahfidzul Al-Qur'an dalam menentukan evaluasi yaitu: setoran keseharian peserta didik, kenaikan surat dengan melihat kelancaran membaca dan kebenaran tajwid yang diucapkan oleh peserta didik. Tyler sebagaimana dikutip oleh Mardapi (2004) menyatakan bahwa evaluasi merupakan proses penentuan sejauhmana tujuan pendidikan tercapai. ${ }^{19}$ Evaluasi yang dilaksanakan di MI Muhammadiyah 02 Pontang Ambulu Kabupaten Jember sesuai dengan pernyataan Tyler untuk menentukan sejauh mana tujuan pembelajaran tahfidzul Al-Qur'an tercapai.

Pelaksanaan Program Tahfidzul Al-Qur'an untuk Peserta Didik Jilid 5 diMI Muhammadiyah 02 Pontang Ambulu Jember

Pelaksanaan program tahfidzul Al-Qur'an untuk peserta didik jilid 5 di MI Muhammadiyah 02 Pontang Ambulu Jember dalam pelaksanaan tujuan yaitu tujuan yang disampaikan sesuai dengan perencanaan yang sudah ditentukan yakni dengan membuat peserta didik mudah menghafal surat

\footnotetext{
${ }^{17}$ Samrodi, dkk, Buku Panduan Program Tahfidzul Al-Qur'an Untuk MI Muhammadiyah Pontang Ambulu Jember. (Jember: MI Muhammadiyah 02 Pontang, 2016).

${ }^{18} \mathrm{R}$ Ibrahim \& Nana Syaodih, Perencanaan Pengajaran, (Jakarta: Rineka Cipta, 2010), 112.

${ }^{19}$ Moh, Sahlan. Evaluasi Pembelajaran Panduan Praktis Bagi Pendidik dan Calon Pendidik. (Jember: STAIN Press, 2013), 9.
} 
Al-Insyiqaq dan Al-Muthoffifin, menambah hafalan surat Al-Insyiqaq dan Al-Muthoffifin, menanamkan cinta Al-Qur'an sejak dini dan membaca surat Al-Insyiqaq dan Al-Muthoffifin sesuai makhraj dan tajwid. Pelaksanaan pembelajaran menurut Suryosubroto adalah proses berlangsungnya belajar mengajar di kelas yang merupakan kegiatan inti dari kegiatan pendidikan di sekolah. Sedangkan menurut Winarno Surachman dikutip oleh Suryosubroto pelaksanaan pembelajaran adalah interaksi guru dan murid dalam rangka menyampaikan bahan pelajaran kepada peserta didik dan untuk mencapai tujuan pengajaran. ${ }^{20}$

Pelaksanaan program tahfidzul Al-Qur'an dalam penyampaian materi yaitu: materi yang disampaikan sesuai dengan perecanaan yang telah direncanakan yaitu Ustadz memberi contoh bacaan surat Al-Insyiqaq dan Al-Muthoffifin 2 dan 3 ayat setiap pembelajaran. Materi pembelajaran merupakan salah satu unsur atau komponen yang penting, artinya untuk mencapai tujuan-tujuan pengajaran materi pelajaran terdiri dari fakta-fakta, generalisasi, konsep, hukum/aturan dan sebagainya, yang mendukung dalam mata pelajaran. ${ }^{21}$ Materi pelajaran berkenaan dengan bahan pelajaran yang harus dikuasai peserta didik sesuai dengan tujuan pembelajaran. materi pelajaran merupakan bagian terpenting dalam proses pembelajaran, bahkan dalam pengajaran yang berpusat pada materi pelajaran, materi pelajaran merupakan inti dari kegiatan pembelajaran. Menurut Subject Centered Teaching keberhasilan suatu proses pembelajaran ditentukan oleh seberapa banyak peserta didik dapat menguasai materi.

Pelaksanaan program tahfidzul Al-Qur'an dalam langkah-langkah metode yaitu: langkah-langkah metode yang dilaksanaka sesuai dengan perencanaan yang telah ditentukan yaitu menggunakan metode tilawati dengan tehnik mendengarkan, menirukan dan membaca bersama-sama

\footnotetext{
${ }^{20}$ Suryosubroto, Proses BelajarMengajar, 36.

${ }^{21}$ Abdurrohimhasan, dkk. Strategi Pembelajaran Al-Quran Metode Tilawati. (Surabaya: Pesantren Al-Qur'an Nurul Falah, 2010), 17.
} 
setelah itu membaca berulang-ulang kemudian setoran materi sebelumnya dan materi yang baru. Metode tilawati adalah metode belajar membaca Al-Quran yang disampaikan secara seimbang antara pembiasaan melalui pembiasaan klasikal. Sebuah metode dikatakan baik dan cocok manakala bisa mengantar kepada tujuan yang dimaksud. Begitupun dalam menghafal surat Al-Insyiqaq dan Al-Muthoffifin, metode yang baik akan berpengaruh kuat terhadap proses hafalan sehingga tercipta keberhasilan dalam menghafal. Urgennya metode dalam proses pendidikan dan pengajaran. Sebuah proses belajar mengajar bisa dikatakan tidak berhasil apabila dalam proses tersebut tidak menggunakan metode. ${ }^{22}$

Pelaksanaan program tahfidzul Al-Qur'an dalam penggunaan media yaitu sesuai dengan perencaanaan yang telah ditentukan yaitu Juz 'Amma, Al-Qur'an dan murottal. Penggunaan media Juz 'Amma dilakukan dengan Ustadz meminta peserta didik membuka Juz 'Amma, peserta didik yang tidak mempunyai Juz 'Amma membuka Al-Qur'an pojok untuk menyimak bacaan yang dibacakan oleh Ustasz. Sedangkan Murottal digunakan untuk mendengarkan surat Al-Insyiqaq dan Al-Muthoffifin. Berdasarkan teori Azhar Arsyad kriteria yang perlu diperhatikan dalam memilih media yaitu sesuai dengan tujuan yang ingin dicapai, tepat untuk mendukung isi pelajaran, praktis, luwes dan bertahan, guru terampil dalam menggunakannya, pengelompokan sasaran. ${ }^{23}$ Penggunaan media di MI Muhammadiyah 02 Pontang Ambulu Jember telah sesuai dengan teori yang dikemukakan oleh Azhar Arsyad. Penggunaan media cetak seperti Juz 'Amma dan Al-Quran. Media dalam metode tilawati ditunjang dengan alat bantu pembelajaran yang menarik seperti peralatan multimedia seperti berupa audio yang didalamnya berisi kumpulan surat yang akan dijelaskan oleh Ustadz dan surat sebelumnya yang sudah dijelaskan. Berdasarkan teori Hujair

\footnotetext{
${ }^{22}$ Ahmad Zainal Abidin, Metode Cepat Menghafal Juz 'Amma. (Yogyakarta: PT Huta Parhapuran, 2016), 10 .

${ }^{23}$ Azhar Arsyad, Media Pembelajaran (Jakarta: Rajawali Pers, 2014), 74-76.
} 
AH Sanaky media audio adalah penyajian pengajaran atau pengetahuan melalui pendidikan audio atau pengalaman mendengar. ${ }^{24}$

Pelaksanaan program tahfidzul Al-Qur'an dalam evaluasi yaitu evaluasi yang dilakukan sesuai dengan perencaanaan yang telah ditentukan yaitu setoran hafalan setiap hari atau setiap akhir pembelajaran dan ketika kenaikan dengan melihat kelancaran membaca dan kebenaran tajwid yang diucapkan oleh peserta didik. Evaluasi merupakan bagian yang penting dalam pembelajaran. Dengan melakukan penilaian, pendidik sebagai pengelola kegiatan pembelajaran dapat mengetahui kemampuan yang dimiliki peserta didik, ketetapan metode mengajar yang digunakan dan keberhasilan peserta didik dalam meraih kompetensi yang telah ditetapkan. Hasil penilaian juga dapat memberikan motivasi kepada peserta didik untuk berprestasi lebih baik. $^{25}$ Evaluasi yang dilaksanakan MI Muhammadiyah 02 untuk peserta didik jilid 5 yaitu dengan evaluasi setoran hafalan keseharian dan kenaikan surat.

\section{Evaluasi Program Tahfidzul Al-Qur'an untuk Peserta Didik Jilid 5 di} MI Muhammadiyah 02 Pontang Ambulu Jember

Evaluasi program tahfidzul Al-Qur'an dalam evaluasi tujuan yaitu tujuan yang sudah ditentukan sudah maksimal dalam menghafal surat Al-Insyiqaq dan Al-Muthoffifin karena setiap pembelajaran peserta didik hanya menghafalkan 2 dan 3 ayat. Tujuan adalah komponen yang utama dalam proses pembelajaran. Apapun yang direncanakan termasuk pengemasan materi pelajaran diarahkan untuk mencapai tujuan pembelajaran secara optimal. ${ }^{26}$ Evaluasi tujuan program tahfidzul Al-Qur'an MI Muhammadiyah 02 Pontang Ambulu Kabupaten Jember sudah maksimal dalam menghafal surat Al-Insyiqaq dan Al-Muthoffifin.

\footnotetext{
${ }^{24}$ Hujair AH Sanaky, Media Pembelajaran Interaktif-Inovatif, (Yogyakarta: Kaukaba Dipantara, 2013), 107.

${ }^{25}$ Anas Sudijono, Pengantar Evaluasi Pendidikan, (Jakarta: Rajawali Pers, 2013), 71.

${ }^{26}$ Wina Sanjaya, Perencanaan Dan Desain Sistem Pembelajaran, 151.
} 
Evaluasi program tahfidzul Al-Qur'an dalam evaluasi materi yaitu: materi yang ditargetkan jilid 5 yaitu menghafal surat Al-Insyiqaq dan Al-Muthoffifin ini tidak mengalami kesulitan karena proses menghafalnya sedikit demi sedikit yang setiap harinya 2 dan 3 ayat. Materi pelajaran merupakan suatu yang disajikan guru untuk diolah dan kemudian dipahami oleh peserta didik, dalam rangka pencapaian tujuan-tujuan instruksional yang telah ditetapkan. Dengan kata lain, materi pembelajaran merupakan salah satu unsur atau komponen yang penting, artinya untuk mencapai tujuan-tujuan pengajaran materi pelajaran terdiri dari fakta-fakta, generalisasi, konsep, hukum/aturan dan sebagainya, yang mendukung dalam mata pelajaran. Materi yang diberikan untuk peserta didik jilid 5 MI Muhammadiyah 02 Pontang Ambulu Kabupaten Jember Surat Al-Insyiqaq dan Al-Muthoffifin sesuai dengan perencanaan dan pelaksanaan.

Evaluasi program tahfidzul Al-Qur'an dalam Evaluasi metode yaitu: metode yang digunakan masih perlu adanya evaluasi atau perbaikan yaitu dengan penambahan metode takrir yaitu untuk memperlancar hafalan (membaca bacaan berulang-ulang) dalam menghafal surat Al-Insyiqaq dan Al-Mutoffifin untuk memudahkan peserta didik dalam menghafal. Sedangkan metode tilawati mempermudah bacaan Al-Qur'an sesuai makhraj dan tajwid. Kata takrir beberapa makna dan pengertian: takrir dengan arti ketetapan/kenyataan Al-Jarjani membedakan antara takrir dengan tahrir. Tahrir menerangkan arti secara kinayah, sedangkan takrir memberikan penjelasan tentang pengertian dan ibarat. Dalam istilah ilmu nahwu, pengertian ini dalam pendidikan lebih dekat dengan usaha kontinuitas dalam belajar untuk dapat meraih hasil yang maksimal. Dalam metode menghafal Al-Qur'an, khususnya Juz 'Amma, arti atau makna dari takrir adalah mengulang hafalan atau men-sima'-kan hafalan yang pernah dihafalkan atau sudah pernah di sima'kan kepada guru tahfizh. Takrir yang dimaksudkan agar hafalan yang pernah dihafalkan tetap terjaga dengan baik. Selain dengan guru, takrir juga dapat dilakukan sendiri dengan maksud melancarkan 
hafalan yang telah dihafal sehingga tidak mudah lupa. Metode yang digunakan peserta didik jilid 5 di MI Muhammadiyah 02 Pontang Ambulu Kabupaten Jember masih perlu adanya evaluasi atau perbaikan dengan penambahan metode takrir. ${ }^{27}$

Evaluasi program tahfidzul Al-Qur'an dalam Evaluasi media yaitu: media yang digunakan sesuai/cocok digunakan menghafal surat Al-Insyiqaq dan Al-Muthoffifin yaitu dengan menggunakan media Juz 'Amma, Al-Qur'an pojok dan murottal. Media pembelajaran dapat diartikan sebagai sesuatu yang mengantarkan pesan pembelajaran antara pemberi pesan kepada penerima pesan. ${ }^{28}$ Media pembelajaran adalah media yang membawa pesan-pesan atau informasi yang bertujuan instruksional atau mengandung maksud-maksud pengajaran. ${ }^{29}$ Evaluasi media untuk peserta didik jilid $5 \mathrm{MI}$ Muhammadiyah 02 Pontang Ambulu Kabupaten Jember Juz 'Amma, Al-Qur'an dan murottal media yang digunakan sudah sesuai/cocok digunakan menghafal surat Al-Insyiqaq dan Al-Muthoffifin.

Evaluasi formatif: evaluasi formatif yang dilakukan setiap akhir pembelajaran dan ketika kenaikan surat. Evaluasi formatif ini berupa bentuk tes lisan karena dengan tes tersebut membuat peserta didik tidak sekedar hafal, lancar, benar makhorijul huruf, tajwidnya dan tidak lupa pada hafalannya

Evaluasi yang pertama yaitu evaluasi harian ini dilakukan setiap hari setelah pembelajaran selesai, kenapa diperlukan evaluasi harian karena ini adalah pembelajaran menghafal yang mana pembelajaran menghafal ini memang sangat diperlukan yang namanya mengulang hafalan yang sebelumnya. Evaluasi yang kedua kenaikan surat dilakukan ketika pembelajaran surat selesai dari ayat pertama hingga ayat terakhir. Dalam evaluasi pembelajaran menghafal surat Al-Insyiqaq dan Al-Muthoffifin yang

\footnotetext{
${ }^{27}$ Ahmad Zainal Abidin, MetodeMenghafal Juz Amma, 23.

${ }^{28}$ Hamdani, Strategi Belajar Mengajar (Bandung: Cv Pustaka Setia, 2011), 243.

${ }^{29}$ Sri Anitah, Media Pembelajaran (Surakarta:Yuma Pustaka, 2010), 4.
} 
digunakan di MI Muhammadiyah 02 Pontang ini memiliki kriteria tersendiri yaitu dengan melihat kesalahan dari ayat yang dihafalkan oleh peserta didik. Jika peserta didik benar semua dan lancar beserta dengan bacaan maka penilaian yang diberikan adalah A, jika peserta didik dalam menghafal lancar dalam tajwidnya maka penilaian yang diberikan adalah $\mathrm{B}$, jika peserta didik dalam menghafal hanya sekedar hafal saja maka penilaian yang diberikan adalah C. Sejatinya evaluasi dalam menghafal Juz 'Amma bertujuan menguji sejauh mana peserta didik menjaga hafalannya agar tidak hilang.

Temuan tersebut kemudian didiskusikan oleh peneliti dengan teori-teori yang relevan dengan fokus penelitian. Teori yang dikembangkan oleh Moh. Sahlan menyatakan bahwa: Evaluasi merupakan penilaian keseluruhan program pendidikan mulai perencanaan suatu program subtansi pendidikan termasuk kurikulum dan penilaian serta pelaksanaanya, pengadaan dan peningkatan kemampuan pendidik, manajemen pendidikan, dan reformasi pendidikan secara keseluruhan. Evaluasi merupakan proses penentuan sejauh mana tujuan pendidikan tercapai. Banyak definisi disampaikan oleh para ahli tetapi pada hakekatnya evaluasi selalu memuat masalah informasi dan kebijakan yaitu informasi tentang pelaksanaan dan keberhasilan suatu program yang selanjutnya digunakan untuk menentukan kebijakan berikutnya. Kalau kita akan mengevaluasi program pembelajaran yang telah dilakukan, maka kita harus mengevaluasi pelaksanaan dan keberhasilan dari program pembelajaran yang telah direncanakan. Hasil evaluasi pembelajaran diharapkan dapat mendorong pendidik mengajar lebih baik dan mendorong peserta didik untuk belajar lebih baik. ${ }^{30}$

Anas Sudijono menyatakan evaluasi formatif yaitu: evaluasi yang dilaksanakan di tengah-tengah atau pada saat berlangsungnya proses pembelajaran, yaitu dilaksanakan pada setiap kali satuan program pembelajaran atau sub pokok bahasan dapat diselesaikan, dengan tujuan

\footnotetext{
${ }^{30}$ Moh. Sahlan, EvaluasiPembelajaran Panduan, 3.
} 
untuk mengetahui sejauh mana peserta didik "telah terbentuk", sesuai dengan tujuan pengajaran yang telah ditentukan. ${ }^{31}$ Evaluasi yang digunakan untuk peserta didik jilid 5 di MI Muhammadiyah 02 Pontang Ambulu Kabupaten Jember yaitu evaluasi formatif yaitu tes dengan tes lisan. Tes lisan digunakan untuk mengukur kemampuan peserta didik dalamberkomunikasi (coomication skill). Tes lisan juga dapat digunakan untuk menguji peserta didik baik secara individu maupun kelompok. Tes ini termasuk tes verbal, yaitu tes soal dan jawabannya menggunakan bahasa lisan. Dimana dalam tesnya dinilai dari hasil setoran setoran setiap hari dan kenaikan surat. Apabila dikaitkan dengan perencanaan dan pelaksanaan maka sudah sesuai dengan rencana dan pelaksanaan.

\section{SIMPULAN}

Berdasarkan hasil analisis dan pembahasan temuan, hasil penelitian ini dapat disimpulkan sebagai berikut: (1) Perencanaan program tahfidzul Al-Qur'an untuk peserta didik jilid 5 di MI Muhammadiyah 02 Pontang Ambulu Jember yaitu: penentuan tujuan hafalan 2 surat Al-Insyiqaq dan Al-Muthoffifin, menanamkan cinta Al-Qur'an sejak dini, Isi materi, menentukan metode, Penentuan media, Penentuan evaluasi. (2) Pelaksanaan program tahfidzul Al-Qur'an untuk peserta didik jilid 5 di MI Muhammadiyah 02 Pontang Ambulu Jember yaitu: peserta didik menghafal surat Al-Insyiqaq dan Al-Muthoffifin, membaca surat sesuai makhraj dan tajwid, Penyampaian materi oleh guru, menggunakan metode tilawati dengan mendengarkan, menirukan, membaca bersama-sama dan berulang-ulang, Penggunaan media Juz 'Amma, Al-Qur'an dan murottal. (3) Evaluasi program tahfidzul Al-Qur'an untuk peserta didik jilid 5 di MI Muhammadiyah 02 Pontang Ambulu Jember yaitu: evaluasi tujuan, evaluasi materi berdasarkan target menghafal surat Al-Insyiqaq dan Al-Muthoffifin

\footnotetext{
${ }^{31}$ Anas Sudijono, Pengantar Evaluasi Pendidikan (Jakarta: Rajawali Pers, 2013), 71-72.
} 
dan tidak mengalami kesulitan, evaluasi metode, evaluasi formatif setiap akhir pembelajaran dan kenaikan surat.

\section{DAFTAR PUSTAKA}

Abidin, Ahmad Zainal. Metode Menghafal Juz 'Amma. Yogyakarta: PT Huta Parhapuran. 2016.

Ahmadi, Abu. Ilmu Pendidikan. Jakarta: Rineka Cipta, 2001.

Anitah, Sri. Media Pembelajaran, Surakarta:Yuma Pustaka, 2010.

Arsyad, Azhar. Media Pembelajaran. Jakarta: Rajawali Pers, 2014.

Departemen Agama RI. Aisyah Al-Qur'an dan Terjemahan Untuk Wanita. Bandung: Jabal. 2010.

Departemen Pendidikan Nasional. Kamus Besar Bahasa Indonesia. Jakarta:Balai Pustaka. 2007.

Ferdinan. Pelaksanaan Progam Tahfidz Al Qur'an (Studi Pesantren Darul Arqam Muhammadiyah Gombara Sulawesi Selatan). Sulawesi: Universitas Muhammadiyah Makassar, Volume 3 No.1. 2018.

Hamdani, Strategi Belajar Mengajar. Bandung: Cv Pustaka Setia. 2011.

Hasan, Abdurrohim dkk. Strategi Pembelajaran Al-Quran Metode Tilawati. Surabaya: Pesantren Al-Qur'an Nurul Falah, 2010.

Intan Alivia Permadani and Abdul Karim. "Penerapan Metode Dirosati Dalam Mengembangkan Kemampuan Baca Sejak Dini Di TPQ Nurul Falah Bringin Lawang Jenggawah". NGARSA: Journal of Dedication Based on Local Wisdom 1, no. 1 (February 24, 2021).

Khuluqo, Ihsan El. Belajar dan Pembelajaran. Yogyakarta: Pustaka Pelajar, 2017.

R Ibrahim \& Nana Syaodih. Perencanaan Pengajaran. Jakarta: Rineka Cipta. 2010.

Rofiul, Wahyudi, dkk. Metode Cepat Hafal Al-Qur'an. Yogyakarta: Semesta Hikmah, 2017.

Rosidi, Ahmad. Strategi Pondok Tahfidz Al-Qur'an Dalam Meningkatkan Motivasi Menghafal Al-Qur'an. Malang: UIN Maulana Malik 
Ibrahim, 2015.

Sa'dulloh. 9 Cara Praktis Menghafal Al-Qu'ran. Jakarta:Gema Insani. 2008.

Sadirman A.M. Interaksi \& Motivasi Belajar Mengajar. Jakarta:PT. Raja Grafindo Persada. 2012.

Sahlan, Moh. Evaluasi Pembelajaran Panduan Praktis Bagi Pendidik dan Calon Pendidik. Jember: STAIN Press. 2013.

Samrodi, dkk. Buku Panduan Program Tahfidzul Al-Qur'an Untuk MI Muhammadiyah Pontang Ambulu Jember. Jember: MI Muhammadiyah 02 Pontang. 2016.

Sanaky, Hujair AH. Media Pembelajaran Interaktif-Inovatif. Yogyakarta: Kaukaba Dipantara, 2013.

Sanjaya, Wina. Perencanaan Dan Desain Sistem Pembelajaran. Jakarta: Prenadamedia Group. 2008.

Sanjaya, Wina. Perencanaan Dan Desain Sistem Pembelajaran. Jakarta: Prenadamedia Group, 2008.

Slameto. Belajar dan Faktor-Faktor Yang Mempengaruhi. Jakarta: Bima Aksara 1988.

Sudijono, Anas. Pengantar Evaluasi Pendidikan. Jakarta: Rajawali Pers, 2013.

Suryosubroto. Proses Belajar Mengajar di Sekolah. Jakarta: Rineka Cipta. 2002.

Undang-Undang No. 20 Tahun 2003 tentang Sisdiknas pasal 3.

Uno, Hamzah B. Perencanaan Pembelajaran. Jakarta: Bumi Aksara, 2016. 